\title{
mediag \\ Media Industries and the Ecological Crisis
}

\author{
Richard Maxwell \\ City University of New York-Queens College \\ richard.maxwell[AT]qc.cuny.edu
}

\begin{abstract}
:
This essay argues that media industry studies should be open to eco-materialist approaches. Whether we study mobile telephony, social media, the network society, or studio operations, we must see these subjects in the ecological context in which they arise and operate. ${ }^{2}$
\end{abstract}

Keywords: Energy, Environment, Digitization, Political Economy, Technology

All of today's large media corporations are studying the ecological costs of their operations and have already instituted some kind of greening strategy in response-even News Corp., owner of climate science denier Fox News, has been greening its operations. While the details vary, these companies share a number of laudable green goals: to reduce energy consumption, increase recycling and reuse of inventory, eliminate waste, encourage employees to be good green citizens, and so on. ${ }^{3}$ But the scholarship on media industries hasn't paid much attention. My hope is that Media Industries journal will change that.

Regardless of naysayers, there is scientific consensus that humans are responsible for harmful climate change caused by the overproduction of carbon dioxide. Ocean acidification is killing off sea habitat, and we've overdosed the planet with nitrogen. Massive levels of conventional pollution are still a problem for the over-developed world and, as we've seen this year in news from Shanghai and elsewhere, in the industrial economies of Asia, too. Many of us of a "certain age" can bear witness to rapidly diminishing biodiversity-this is the Earth's sixth great extinction - and we're responsible for it.

Climate and environmental scientists have different ways of explaining the central point of the eco-crisis: that human activity, fueled by a growth-obsessed political economic order, has crossed the line of sustainability. The latter can be defined as the balance between what the Earth can give to support human activity and what the Earth can safely re-absorb from those activities. This balancing function has been called the "scientific prerequisites for ecological sustainability," or more simply, our "planetary boundaries." 4

But why is this important for media industry studies? 
The technologies upon which media industry studies are predicated not only provide the kind of content, institutions, and audiences that form the subject matter of this journal. They also depend on human exploitation of the environment-from the minerals, mechanics, and chemistry used to make them to the energy used to power them.

Media technology is proliferating, with spending on consumer electronics alone reaching \$1 trillion in 2012, and rising to nearly $\$ 1.1$ trillion in 2013, which matched overall annual spending increases of 4 to 5 percent on all information technology for that period. This added up to about $\$ 3.7$ trillion in spending on consumer electronics by the end of 2013. 5 The major portion of this growth is in sales of mobile devices.

There are many relevant environmental problems associated with our love affair with media technology, but I'll use the issue of energy consumption to illustrate the vital importance of ecocriticism to media industry studies.

I know it's an obvious point, but for some reason we tend to forget that all these gadgets need to be plugged into the electric grid - and remember that batteries, too, have built-in energy costs in production, usage, and disposal. Over ten billion high-tech devices around the world need electricity today. And according to the International Energy Agency (IEA), all this media technology consumes about 15 percent of the total global residential energy in use.

Without any changes to this trend, the residential electricity needed to power this whiz-bang stuff will rise to 30 percent of global consumption by 2022 and 45 percent by 2030, according to the IEA.

Keep in mind that residential use refers to operational energy and not to the energy consumed in the manufacturing stage of information and communication technologies. Energy used in the manufacturing of laptops, for example, is 64 percent of the total that's used in a laptop's lifecycle-and this does not account for the energy used to make chemicals and gases that go into the production of semiconductors or the energy used to dispose or recycle the damn things. ${ }^{6}$ This problem of measurement applies to all the hardware used in the industry we study.

When we connect the dots between our high-tech lifestyle and the power grid, including the electricity it takes to manufacture and distribute these gadgets, we are talking about aggregate carbon emissions on a scale that matches the footprint of the aerospace industry.

And the story on the so-called cloud is similar.

Data centers' energy demand doubled in the first five years of the new century and continues to rise at a steady pace, with business practices that range from serious efforts to reduce reliance on coal-fired energy to widespread examples of waste and thoughtless energy management.

If Google gets its way, small-scale, inefficient data centers will disappear altogether, replaced by the likes of Google, Facebook, IBM, Microsoft, Amazon, and other mega-operators of the cloud. Google backs its play with research showing that the centralization of cloud computing into massive infrastructure systems promises to reduce current energy consumption by 87 percent. ${ }^{7}$ That would certainly be a positive change, considering that at their current rate of demand, data centers are such ravenous hogs that, according to Greenpeace, if the cloud were a country it would be the fifth largest energy consumer in the world.

As the media industry moves toward increasing internet delivery of content and audiences via the cloud, the problem of energy provision and consumption becomes an important one for 
media industry research-a problem complicated by the unsustainable structure of mobile communication business.

A Bell Labs/University of Melbourne study estimates that 90 percent of the total energy consumed by the wireless cloud is attributable to access providers - this is not counting the energy used by the devices themselves. ${ }^{8}$ The researchers point to the relatively meager 9 percent share of total energy consumption attributable to data centers.

Behind these projections of rising energy demand is the tremendous growth in sales of electronic equipment that I referred to earlier. This growth is now mostly made up of sales of mobile devices like tablets, notebooks, and smartphones - a quarter of all sales is attributable to the US alone.

Such growth in mobile computing is really astounding, and really bad for the environment. It's the result in part of unrelenting marketing of wireless gadgets promoted as tools to keep us constantly connected to each other and the network. We are told that the convergence around digital technology along with mobility and other supposed innovations of the network society pose big challenges to media industries today.

From an eco-materialist perspective, the intimate relation of media technology and environmental decline poses an important challenge to media industry scholarship. For me, this means reading beyond conventional industry research to study, inter alia, the science on climate change, lifecycle assessment, and the chemistry associated with the production, use, and disposal of media technologies. Most importantly, it means acknowledging the urgent nature of the ecological crisis. Only then can we perform a critical evaluation of the greening strategies currently underway in the media industries.

The environmental problems of media industries should not be understood as a narrow matter relevant only to this sector. The eco-crisis affects every organism on the planet, making this particular problem of general interest-and this means the sub-discipline of media industry studies must venture out into the critique of the wider political economy and ask what kind of society we want to live in. The answer will determine whether our media and cultural industries are rooted in values of sustainability or constrained by a political economic order based on unending and unsustainable growth.

${ }^{1}$ Richard Maxwell is Professor and Chair of Media Studies at Queens College, City University of New York. He has published widely on a range of topics: media and the environment; broadcast reform during Spain's democratic transition; Hollywood's international dominance; media politics in the post-9/11 era; marketing research and the surveillance society; and the impact of political economic forces in daily life and culture.

2 A version of this essay was presented in Dublin at the International Association for Media and Communication Research in July 2013. See also Richard Maxwell and Toby Miller, Greening the Media (Oxford: Oxford University Press, 2012).

3 For examples, see the site Producers Guild of America's Green.

4 Johan Rockstrom et al., "Planetary Boundaries: Exploring the Safe Operating Space for Humanity," Ecology and Society 14, no. 2 (2009); Thomas Schauer, The Sustainable Information Society: Vision and Risks (Vienna: European Support Centre of the Club of Rome, 2003). 
5 Kyle Brown, "Consumer Electronics Show 2013: Global Gadget Spending to Top \$1 Trillion this Year," globalEDGE, January 8, 2013,; Valli Meenakshi Ramanathan, “Global IT Spending Pegged at \$3.7 Trillion; Gadget Spending Forecast at \$1.1 trillion in 2013," International Business Times, January 7, 2013.

6 Eric Williams, "Environmental Effects of Information and Communications Technologies," Nature 479 (2011): 354-358.

7 Ucilia Wang, “A Google-Funded Study Quantifies Cloud Computing's Environmental Benefits," Forbes, June 11, 2013.

8 Centre for Energy-Efficient Telecommunications, "The Power of Wireless Cloud: An Analysis of the Energy Consumption of Wireless Cloud," (Melbourne: Bell Labs and University of Melbourne, April 2013).

\section{Bibliography}

Brown, Kyle. "Consumer Electronics Show 2013: Global Gadget Spending to Top \$1 Trillion this Year." globalEDGE, January 8, 2013. .

Centre for Energy-Efficient Telecommunications. "The Power of Wireless Cloud: An Analysis of the Energy Consumption of Wireless Cloud." Melbourne: Bell Labs and University of Melbourne, April 2013.

Maxwell, Richard and Toby Miller. Greening the Media. Oxford: Oxford University Press, 2012.

Ramanathan, Valli Meenakshi. “Global IT Spending Pegged at \$3.7 Trillion; Gadget Spending Forecast at \$1.1 trillion in 2013." International Business Times, last modified January 7, 2013.

Rockstrom, Johan, Will Steffen, Kevin Noone, Åsa Persson, F. Stuart III Chapin, Eric Lambin, Timothy M. Lenton, Martin Scheffer, Carl Folke, Hans Joachim Schellnhuber, et al. "Planetary Boundaries: Exploring the Safe Operating Space for Humanity." Ecology and Society 14, no. 2 (2009).

Schauer, Thomas. The Sustainable Information Society: Vision and Risks. Vienna: European Support Centre of the Club of Rome, 2003.

Wang, Ucilia. “A Google-Funded Study Quantifies Cloud Computing's Environmental Benefits." Forbes, June 11, 2013.

Williams, Eric. "Environmental Effects of Information and Communications Technologies." Nature 479 (2011): 354-358.

\section{(cc) Br-NC-ND}

Copyright (C) 2014 (Richard Maxwell). Media Industries is an open-access, peer-reviewed, online academic journal. As such, we aim to participate in the open exchange of information. This work is licensed under a Creative Commons Attribution Noncommercial No Derivatives (by-nc-nd) License. Under this license, this work is available for sharing and noncommercial distribution provided the appropriate attribution is given. 